\title{
Dual paraneoplastic syndromes in a patient with small cell lung cancer: a case report
}

\author{
Kristin Coners, Scott E Woods ${ }^{*}$ and Michael Webb
}

\begin{abstract}
Introduction: We describe the case of a patient with small cell lung cancer and dual paraneoplastic syndromes involving adrenocorticotropic hormone and calcitonin. To the best of our knowledge, dual paraneoplastic syndromes involving these two hormones have not been previously reported in the literature.
\end{abstract}

Case presentation: A 74-year-old Caucasian woman presented with a left hilar mass and metastatic disease in the liver and right adrenal gland. The patient complained only of intermittent diarrhea. Her laboratory values exhibited metabolic alkalosis with hypokalemia, hypocalcemia, hypomagnesemia, hypophosphatemia, and hyperglycemia.

Conclusion: We discuss the work-up and treatment of the patient's unusual laboratory presentation with two concurrent paraneoplastic syndromes.

\section{Introduction}

Although paraneoplastic syndromes occur commonly, dual paraneoplastic syndromes occurring simultaneously in the same patient are very rare. We describe the case of a patient with small cell lung cancer and dual paraneoplastic syndromes involving adrenocorticotropic hormone and calcitonin.

\section{Case report}

A 74-year-old Caucasian woman presented to the Emergency Department (ED) at our hospital with acute onset of thoracic back pain. Her medical history included hypertension, hypothyroidism, a right hip replacement, and diffuse large cell lymphoma in 1985, which was treated successfully with chemotherapy and radiation. She was a previous smoker who had quit approximately five years earlier. Upon review of her systems, she complained only of some diarrhea that she had experienced intermittently for one year. Her medications included atenolol, hydrochlorothiazide, and levothyroxine. Her vital signs and physical examination in the ED were remarkable only for thoracic spine tenderness. X-rays revealed a compression fracture of her T9 vertebra (age indeterminate) and a new left hilar mass. A renal panel revealed the following abnormalities: potassium 2.7

\footnotetext{
* Correspondence: Liverdoctor@yahoo.com

* Correspondence: Liverdoctor@yahoo.com
Bethesda Family Medicine Residency Program, 4411 Montgomery Road, Suite 200, Cincinnati, OH 45212, USA
}

$\mathrm{mEq} / \mathrm{l}$ (lower limit of normal (LLN), $3.5 \mathrm{mEq} / \mathrm{l}$ ), chloride $74 \mathrm{mEq} / \mathrm{l}$ (LLN, $101 \mathrm{mEq} / \mathrm{l}$ ), bicarbonate $47 \mathrm{mM} / 1$ (upper limit of normal (ULN), $36 \mathrm{mM} / \mathrm{l}$ ), glucose 198 $\mathrm{mg} / \mathrm{dl}$, blood urea nitrogen (BUN) $38 \mathrm{mg} / \mathrm{dl}$ (ULN, 20 $\mathrm{mg} / \mathrm{dl}$ ), and creatinine $1.3 \mathrm{md} / \mathrm{dl}(\mathrm{ULN}, 1.2 \mathrm{md} / \mathrm{dl}$ ), with normal levels of sodium $(137 \mathrm{mEq} / \mathrm{l})$, total calcium $(9.1$ $\mathrm{mg} / \mathrm{dl})$, and magnesium $(1.7 \mathrm{mEq} / \mathrm{L})$. A computed tomography scan showed a left hilar mass with metastatic disease in the liver and right adrenal gland. There was no evidence of a pathological fracture of her ninth thoracic vertebrae.

The patient was admitted to the hospital for hydration and electrolyte replacement. During her hospital stay, the patient's blood sugar was elevated, and she received insulin coverage. She also received an oral bisphosphonate. Additional diagnostic work-up included a stool culture and testing for Clostridium difficile toxins A and $B$, which were negative. Interventional radiology was performed, and a biopsy of one of the liver lesions was obtained. The patient was discharged to home five days after admission with instructions to discontinue hydrochlorothiazide and begin taking spironolactone $25 \mathrm{mg}$ twice daily, alendronate $70 \mathrm{mg}$ weekly, and metformin $500 \mathrm{mg}$ twice daily. Her renal panel at the time of discharge showed significant improvement: sodium 142 $\mathrm{mEq} / \mathrm{l}$ (normal), potassium $3.3 \mathrm{mEq} / 1$ (LLN, $3.5 \mathrm{mEq} / \mathrm{l}$ ), chloride $102 \mathrm{mEq} / \mathrm{l}$ (normal), bicarbonate $32 \mathrm{mM} / \mathrm{l}$ (normal), glucose $132 \mathrm{mg} / \mathrm{dl}$, BUN $35 \mathrm{mg} / \mathrm{dl}$ (ULN, $20 \mathrm{mg} /$ 
$\mathrm{dl}$ ), creatinine $1.0 \mathrm{md} / \mathrm{dl}$ (normal), and total calcium 8.1 $\mathrm{mg} / \mathrm{dl}$ (LLN, $8.5 \mathrm{mg} / \mathrm{dl}$ ). She was instructed to follow up with her oncologist for biopsy results.

The patient re-presented to the ED four days after her discharge with complaints of worsening diarrhea. Aside from an elevated blood pressure of $164 / 76 \mathrm{mmHg}$, her physical examination and vital signs were again unremarkable. Her renal panel now showed sodium 141 $\mathrm{mEq} / \mathrm{l}$, potassium $1.9 \mathrm{mEq} / \mathrm{l}$, chloride $95 \mathrm{mEq} / \mathrm{l}$, bicarbonate $30 \mathrm{mM} / \mathrm{L}$, glucose $177 \mathrm{mg} / \mathrm{dl}$, BUN $46 \mathrm{mg} / \mathrm{dl}$, creatinine $1.4 \mathrm{md} / \mathrm{dl}$, total calcium $6.2 \mathrm{mg} / \mathrm{dl}$, ionized calcium $2.7 \mathrm{mg} / \mathrm{dl}$ (LLN, $4.6 \mathrm{mg} / \mathrm{dl}$ ), magnesium $1 \mathrm{mEq} /$ $\mathrm{L}$ (LLN, $1.4 \mathrm{mEq} / \mathrm{L}$ ), phosphorous $2.1 \mathrm{mg} / \mathrm{dl}$ (LLN, 2.5 $\mathrm{mg} / \mathrm{dl})$. The pathology report diagnosed her tumor as small cell lung cancer (SCLC).

Our residency program admitted the patient for hydration, electrolyte replacement, and further work-up. Stool studies including ova and parasites, repeat culture, and Clostridium difficile toxin were negative. A gastroenterologist performed a flexible sigmoidoscopy and reported that the colonic mucosa appeared normal. Biopsies showed minimal and focal active inflammation consistent with focal active colitis of uncertain origin. The biopsy did not reveal any evidence of architectural distortion consistent with inflammatory bowel disease or any evidence of lymphocytic or collagenous colitis.

We conducted serum testing to uncover a possible paraneoplastic cause for the patient's symptoms. Her vasoactive intestine peptide, pancreatic polypeptide, gastrin, serum aldosterone, plasma renin activity, T4, thyroid-stimulating hormone, and 1,25-hydroxy vitamin $\mathrm{D}$ levels were all within normal limits. We did discover elevations in the patient's calcitonin $(81.8 \mathrm{pg} / \mathrm{ml}$; ULN, $4.6 \mathrm{pg} / \mathrm{ml})$ and midnight cortisol $(80.9 \mu \mathrm{g} / \mathrm{dl}$; ULN, $10 \mu \mathrm{g} / \mathrm{dl})$. Her adrenocorticotropin hormone (ACTH) level was $52 \mathrm{pg} / \mathrm{ml}$ (normal range, 6 to $58 \mathrm{pg} / \mathrm{ml}$ ). We then performed an overnight 8 mg dexamethasone suppression test. The patient's cortisol failed to adequately suppress, with pre- and post-test values of $68.5 \mu \mathrm{g} / \mathrm{dl}$ and $65.5 \mu \mathrm{g} / \mathrm{dl}$, respectively. Additional abnormalities included an intact parathyroid hormone level of $408 \mathrm{pg} / \mathrm{ml}$ (ULN, $65 \mathrm{pg} / \mathrm{ml}$ ) and a 1,25-hydroxy vitamin D level of $14 \mathrm{ng} / \mathrm{ml}$ (LLN, $20 \mathrm{ng} / \mathrm{ml}$ ).

We treated the patient with oral ketoconazole and somatostatin (initially every eight hours subcutaneously and later somatostatin long-acting release intramuscularly). The oncology department also began chemotherapy with etoposide and carboplatin. The patient's diarrhea did improve, as did her laboratory values. Her calcitonin decreased to $31.3 \mathrm{pg} / \mathrm{ml}$, and her midnight cortisol fell to $19.4 \mu \mathrm{g} / \mathrm{dl}$. Unfortunately, the patient's condition deteriorated with the initial chemotherapy, and she chose to discontinue therapy. She was discharged to hospice care.

\section{Discussion}

SCLC is the most common cancer histology associated with paraneoplastic syndromes. Paraneoplastic syndromes are divided into two categories: ectopic production of biologically active proteins produced by the cancer cells and cell-mediated immune responses targeted against neural tissue (Table 1). Patients can present with multiple paraneoplastic syndromes at the same time, especially when the tumor arises from neuroendocrine cells. Although rare, there have been reports in the literature of patients with two or more paraneoplastic syndromes involving SCLC [1-5]. We also found a single report of a patient with two sequential paraneoplastic syndromes concurrently with SCLC [6]. Our case, however, is the only one reporting SCLC secreting both ACTH and calcitonin at the same time.

We believe that two paraneoplastic syndromes derived from SCLC affected this patient (ACTH and calcitonin). Ectopic ACTH secretion caused new-onset diabetes mellitus and likely contributed to hypokalemia, metabolic alkalosis, thoracic compression fracture, hypertension, and emotional liability. Because of a midnight cortisol level of $80.9 \mu \mathrm{g} / \mathrm{dl}$ and a high index of suspicion, we bypassed a 24-hour urinary cortisol test and performed an overnight $8 \mathrm{mg}$ dexamethasone suppression test to determine the source of her hypercortisolism. The patient's cortisol level failed to suppress by $68 \%$, and we made a presumptive diagnosis that her tumor was secreting ectopic ACTH. Given her high normal ACTH values, we did attempt to check her ACTH level by radioimmunoassay to evaluate for the presence of "big ACTH" particles not identified by immunoradiometric assay. Unfortunately, the laboratory mistakenly ran the wrong study. We also wished to obtain a corticotropin-releasing hormone level, but the patient elected hospice care prior to this hormone being drawn.

In addition to apparent ectopic ACTH, we further postulate that ectopic secretion of calcitonin contributed to the patient's profuse diarrhea. SCLC secreting calcitonin is extremely rare but has been reported [7]. Breast cancer and medullary thyroid cancer more commonly secrete calcitonin. The patient's diarrhea had started one year prior to her initial presentation and worsened substantially before her hospital admission. In total, the patient had four tests for Clostridium difficile, two stool cultures, and one test for ova and parasites, all of which were negative. She had a normal endoscopy, and her pathology report found focal active colitis of unclear etiology. There was no evidence to suggest inflammatory bowel disease, and the patient had not been taking medications that would have caused this pathology.

Calcitonin has been known to cause diarrhea in the spectrum of Verner-Morrison syndrome. We believe 
Table 1 Paraneoplastic syndromes associated with small cell lung cancer ${ }^{a}$

\begin{tabular}{|c|c|c|c|c|c|}
\hline \multirow[b]{2}{*}{ Clinical syndrome } & \multicolumn{2}{|c|}{ Ectopic hormone-associated syndromes } & \multicolumn{3}{|c|}{ Immune-mediated neurologic syndromes } \\
\hline & Incidence & SCLC hormone & Incidence & Antibody & SCLC-expressed gene or protein \\
\hline Ectopic Cushing's syndrome & $5 \%$ & $\mathrm{ACTH}$ & & & \\
\hline Hyponatremia of malignancy & $15 \%$ & AVP, CRH (rare) & & & \\
\hline Hypertension & $<1 \%$ & Renin & & & \\
\hline Amenorrhea, galactorrhea & $<1 \%$ & Prolactin, $\mathrm{GH}$ & & & \\
\hline Hyperamylasemia & $<1 \%$ & Salivary anylase & & & \\
\hline
\end{tabular}

\author{
Lambert-Eaton myasthenic \\ syndrome \\ Encephalomyelitis \\ Sensory neuropathy \\ Cerebellar degeneration
}

Retinopathy

Stiff-person syndrome

(encephalitis)

Opsoclonus, myoclonus

$\begin{array}{ccc}1 \% & \text { Anti-VGCC } & \text { Synaptotagmin, MysB } \\ <1 \% & \text { Anti-Hu } & \text { HuD, HuC, Hel-N1, N2 } \\ <1 \% & \text { Anti-Hu } & \text { HuD, HuC, Hel-N1, N2 } \\ <1 \% & \text { Anti-Hu } & \text { HuD, HuC, Hel-N1, N2 } \\ & \text { Anti-VJCC, MysB } & \text { Synaptotagmin } \\ & \text { Anti-Ri } & \text { Nova-1 } \\ & \text { Anti-Yo } & \text { CDR-34 } \\ <1 \% & \text { Anti-CAR } & \text { Recoverin } \\ <1 \% & \text { Anti-amphiphysin } & \text { Amphiphysin } \\ & \text { Anti-Hu } & \text { HuD, HuC, Hel-N1, N2 } \\ <1 \% & \text { Anti-Ri } & \text { Nova-1 } \\ & & \text { HuD, HuC, Hel-N1, N2 } \\ & & \text { Synaptotagmin } \\ & & \text { Nova-1 }\end{array}$

${ }^{a} \mathrm{SCLC}$, small cell lung cancer; ACTH, adrenocorticotropin hormone; AVP, arginine vasopressin; $\mathrm{CRH}$, corticotropin-releasing hormone; GH, growth hormone; VGCC, voltage-gated calcium channel; MysB,; HuD, Human Neuronal Protein D; HuC, Human Neuronal Protein C; Hel-N1,; VJCC, Ri,; Yo,; CDR-34,; anti-CAR, anti-coxsackie adenovirus receptor.

Reprinted with permission from Gandhi L, Johnson BE: Paraneoplastic syndromes associated with small cell lung cancer. J Natl Compr Canc Netw 2006, 4:631-638 [12].

that our patient did not display all of the electrolyte abnormalities generally seen in patients with this syndrome (hypokalemia, achlorhydria, metabolic acidosis, and hypercalcemia) because of ectopic ACTH secretion and previous treatment with a bisphosphonate. More specifically, the patient's diarrhea should have produced metabolic acidosis; however, she possessed a metabolic alkalosis with a $\delta$-gap of 46 caused by excessive cortisol secretion and dehydration. In addition, the patient's hypokalemia was secondary to severe alkalosis, diarrhea, and excessive cortisol secretion. The patient's hypocalcemia resulted from increased gastrointestinal losses, acute critical illness, vitamin D deficiency, and renal insufficiency with secondary hyperparathyroidism.

When surgical therapy is not an option, ketoconazole is the best therapy for treating patients with SCLC and ectopic ACTH secretion [8]. Ketoconazole therapy results in biochemical and hormonal improvement for most patients with excessive cortisol secretion [9]. It has few adverse effects, but may impair the cortisol response to stress. After our patient's treatment with ketoconazole and somatostatin, her diarrhea did improve, as did her laboratory values. We feel that treatment with ketoconazole and somatostatin did benefit the patient, given that chemotherapy had failed to substantially reduce her tumor burden as demonstrated on subsequent imaging.

SCLC accounts for approximately $15 \%$ of all bronchogenic carcinomas [10]. The average age at diagnosis is 71 years. About $30 \%$ of patients with SCLC have limited-stage disease (cancer limited to one hemithorax and lymph nodes on the same side of the chest). Patients with limited-stage disease have a median survival approaching two years and a $14 \%$ five-year survival rate. Patients with extensive disease have a median survival of less than one year [10]. Patients with SCLC and ectopic $\mathrm{ACTH}$ secretion tend to have more extensive disease and exhibit less response to chemotherapy, and they are more likely to die prematurely [11].

\section{Consent}

Written informed consent was obtained from the patient for publication of this case report and any accompanying images. A copy of the written consent is available for review by the Editor-in-Chief of this journal.

\section{Authors' contributions}

KC collected all of the patient data and wrote the initial draft of the manuscript. SW checked all of the data for accuracy and did considerable 
writing and formatting of the manuscript for publication. MW made sure that all appropriate laboratory studies were performed for a precise diagnosis and reviewed the manuscript for accuracy. All authors approved the final manuscript.

\section{Competing interests}

The authors declare that they have no competing interests.

Received: 20 September 2010 Accepted: 19 July 2011

Published: 19 July 2011

\section{References}

1. Gropp C, Havemann K, Scheuer A: Ectopic hormones in lung cancer patients at diagnosis and during therapy. Cancer 1980, 46:347-354.

2. Suzuki H, Tsutsumi Y, Yamaguchi K, Abe K, Yokoyama T: Small cell lung carcinoma with ectopic adrenocorticotropic hormone and antidiuretic hormone syndromes: a case report. Jpn J Clin Oncol 1984, 14:129-137.

3. Shaker JL, Brickner RC, Divgi AB, Raff H, Findling JW: Case report: renal phosphate wasting, syndrome of inappropriate antidiuretic hormone, and ectopic corticotropin production in small cell carcinoma. Am J Med Sci 1995, 310:38-41.

4. Pierce ST, Metcalfe M, Banks ER, O'Daniel ME, DeSimone P: Small cell carcinoma with two paraendocrine syndromes. Cancer 1992, 69:2258-2261.

5. Castro Cabezas M, Vrinten DH, Burgers JA, Croughs RJ: Central diabetes insipidus and Cushing's syndrome due to ectopic ACTH production by disseminated small cell lung cancer: a case report. Neth J Med 1998, 53:32-36.

6. Mayer S, Cypess AM, Kocher ON, Berman SM, Huberman MS, Hartzband PI, Halmos B: Uncommon presentations of some common malignancies: Case 1. Sequential paraneoplastic endocrine syndromes in small-cell lung cancer. J Clin Oncol 2005, 23:1312-1314.

7. The Merck Manuals Online Medical Library. [http://www.merck.com/ mmpe].

8. Biller BM, Grossman AB, Stewart PM, Melmed S, Bertagna X, Bertherat J, Buchfelder M, Colao A, Hermus AR, Hofland L, Klibanski A, Lacroix A, Lindsay JR, Newell-Price J, Nieman LK, Petersenn S, Sonino N, Stalla GK, Swearingen B, Vance ML, Wass JA, Boscaro M: Treatment of adrenocorticotropin-dependent Cushing's syndrome: a consensus statement. J Clin Endocrinol Metab 2008, 93:2454-2462.

9. Winquist EW, Laskey J, Crump M, Khamsi F, Shepherd FA: Ketoconazole in the management of paraneoplastic Cushing's syndrome secondary to ectopic adrenocorticotropin production. J Clin Oncol 1995, 13:157-164.

10. American Cancer Society: Information and Resources for Cancer. [http:// www.cancer.org/].

11. Collichio FA, Woolf PD, Brower M: Management of patients with small cell carcinoma and the syndrome of ectopic corticotropin secretion. Cancer 1994, 73:1361-1367.

12. Gandhi L, Johnson BE: Paraneoplastic syndromes associated with small cell lung cancer. J Natl Compr Canc Netw 2006, 4:631-638.

doi:10.1186/1752-1947-5-318

Cite this article as: Coners et al: Dual paraneoplastic syndromes in a patient with small cell lung cancer: a case report. Journal of Medical Case Reports 2011 5:318.

\section{Submit your next manuscript to BioMed Central and take full advantage of:}

- Convenient online submission

- Thorough peer review

- No space constraints or color figure charges

- Immediate publication on acceptance

- Inclusion in PubMed, CAS, Scopus and Google Scholar

- Research which is freely available for redistribution

Submit your manuscript at www.biomedcentral.com/submit 